\title{
GUIDELINES FOR CONTRIBUTORS
}

\section{GENERAL INFORMATION}

Manuscripts are considered for publication on the understanding that they are not concurrently under consideration elsewhere and that the material-in substance as well as form-has not been previously published.

Three copies of the manuseript should be submitted.

Authors should identify themselves only on a separate title page that provides name, mailing address, and telephone number. Authors must also remember not to identify themselves in the body of the manuscript; specifically, references to their own work in the text should be in the third person, and citations should be written without possessive pronouns-not "See my ...."

Potential contributors should initially submit hard copy, not diskettes, but it will save considerable work for all parties in the event of acceptance if authors follow a few rules from the beginning:

- In general, use as few formatting commands as possible.

- Left justify text.

. Do not hyphenate words at the end of lines.

- ALL material-including extracted quotations and notes-must be double spaced.

- Notes should be numbered consecutively and citations should be placed as footnotes or endnotes formatted as indicated by The Chicago Manual of Style (1993).

- Each table and figure must be accompanied by a complete source.

Each article should be accompanied by an abstract of 75-100 words outlining the main point(s) of the paper and placing the article in context. Subheads should be used to divide the manuscript into three or four sections (or more, depending on length). We do not have an upper or lower page limit, but articles usually run between 25 and 50 typescript pages, including notes and other material.

We are always eager to publish illustrations, but authors should not include originals of illustrative materials at the time of submission; photocopies of such material may be included. Authors are responsible for obtaining all illustrative materials and permissions for reproduction, and for writing captions.

Authors of accepted manuscripts will receive two copies of the issue in which the article appears, and twenty-five free offprints.

\section{Manuscript Preparation}

We use the 14th edition of The Chicago Manual of Style (1993) and spell and hyphenate words according to Webster's Ninth New Collegiate Dictionary.

The journal encourages authors to use gender-neutral prose in all cases where it is not anachronistic to do so; male nouns and pronouns should not be used to refer to people of both sexes. We use the day-month-year form for dates, as 11 February 1998. Double quotation marks should be used for journal titles and direct quotation; single quotation marks are used for quoted material inside quotations.

\section{Sample Citation Forms}

Book: Alfred D. Chandler, Jr., The Visible Hand: The Managerial Revolution in American Business (Cambridge, Mass., 1977), 321-22.

Journal: Charles Cheape, "Not Politicians but Sound Businessmen: Norton Company and the Third Reich," Business History Review 62 (Autumn 1988): 444-66.

Note that we do not include the publisher in book citations. We do not use loc. cit., op. cit., or idem., but ibid. (not italicized) may be used. 


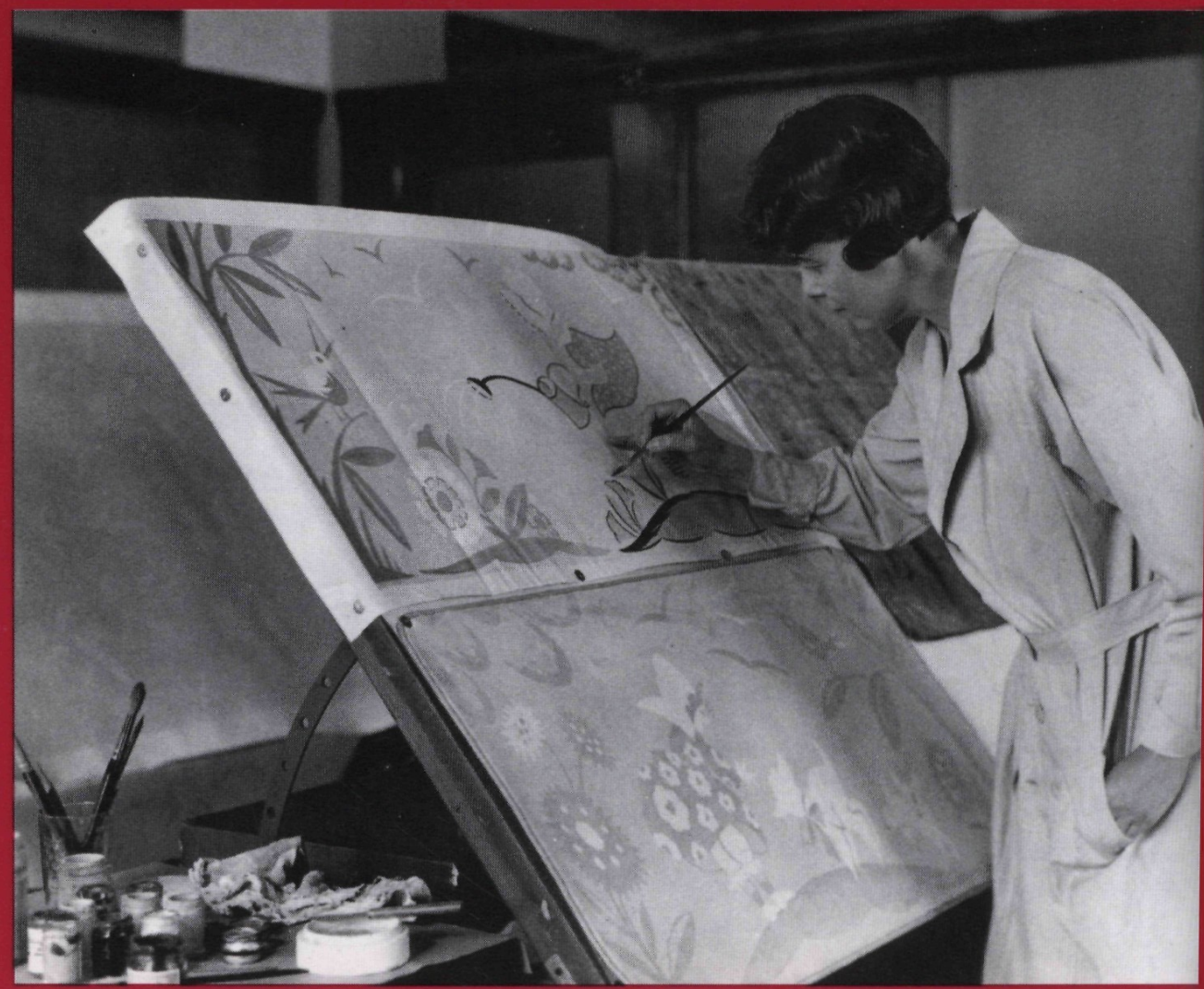

"Designing at Shelton Looms," 1933. Lewis Wickes Hine, photographer.

\section{||||||||||||||||||||||||||||||||||||||||||||||||||||||}

